\title{
Two Replication Determinants of an Antibiotic-resistance Plasmid, pTB19, from a Thermophilic Bacillus
}

\author{
By TADAYUKI IMANAKA, ${ }^{*}$ TAKASHI ANO, MIKIO FUJII \\ AND SHUICHI AIBA \\ Department of Fermentation Technology, Faculty of Engineering, Osaka University, \\ Yamada-oka, Suita-shi, Osaka 565, Japan
}

(Received 20 December 1983)

Two different replication determinants were found on an antibiotic resistance plasmid, pTB19, from a thermophilic bacillus. One replication determinant (designated RepA) was functional only in Bacillus subtilis, whereas the other (designated RepB) functioned in both B. subtilis and Bacillus stearothermophilus. A deletion plasmid, pTB90, carrying the RepB derived from pTB19 coincidentally contained the specific $1.0 \mathrm{MDal}$ Eco RI fragment of a cryptic plasmid pBSO2 from $B$. stearothermophilus. The presence of this 1.0 MDal Eco RI fragment in various deletion plasmids from pTB90 increased transformation frequencies for $B$. stearothermophilus $10^{3}$ to $10^{4}$ times and lowered plasmid copy numbers in the host strain to about one-tenth of those found for plasmids lacking this fragment.

\section{INTRODUCTION}

We have isolated the drug-resistance plasmid pTB19 (17.2 MDal) that specifies resistance to both kanamycin and tetracycline from a thermophilic bacillus and constructed some deletion plasmids from it (Imanaka et al., 1981 a, 1982). Among these deletants, pTB90, like the original plasmid pTB19, could transform both Bacillus subtilis and Bacillus stearothermophilus, whereas pTB51, pTB52 and pTB53 could replicate only in B. subtilis (Imanaka et al., 1982). The success or failure of transformation in both strains depended clearly on the species of plasmid DNA. This observation stimulated further study on the difference or identity of the regulation mechanisms of plasmid DNA replication between mesophiles and thermophiles.

In this paper we describe the finding of two replication determinants on pTB19, and a specific DNA fragment (1.0 MDal EcoRI fragment of pTB90) which could affect one of the two replication determinants in $B$. stearothermophilus was characterized.

\section{METHODS}

Media and materials. All the media used in this work have been described previously (Imanaka et al., 1981 a, 1982). Unless otherwise specified, all chemicals used in this work came from the same sources as described in the previous papers (Imanaka et al., 1981 a, 1982).

Bacterial strains and plasmids. These are listed in Table 1. The restriction endonuclease cleavage maps of these plasmids are shown in Fig. 1. Bacillus stearothermophilus CU21, which is a cured strain from the streptomycinresistant strain S1 carrying a cryptic plasmid pBSO1, was used as the recipient in transformation (Imanaka et al., 1982). However, during the process of transformation some colonies of this strain CU21 fortuitously carrying another cryptic plasmid were observed. This plasmid, designated pBSO2, was larger than pBSO1; it is described later in this paper.

Preparation of plasmid and chromosomal DNA. Plasmid DNA was prepared by either the rapid alkaline extraction method or the $\mathrm{CsCl}$-ethidium bromide equilibrium density-gradient centrifugation, as described by Imanaka et al. (1982). Chromosomal DNA was prepared as described by Imanaka et al. (1981 b).

Abbreviations: Km, kanamycin; Tc, tetracycline. 
Table 1. Bacterial strains and plasmids

Strain

B. stearothermophilus CU21

B. subtilis MI113

Plasmid Mol. wt (MDal)

pTB19 $17 \cdot 2$

pTB51 8.4

pTB52 $7 \cdot 0$

pTB53 $11 \cdot 2$

pTB90 6.7

pBSO1 18.3

pBSO2 $19 \cdot 5$

pUB110 3.0

pUB111 4.0
Characteristics*

Str ${ }^{r}$

$\arg -15 \operatorname{trp} C 2 \mathrm{r}_{\mathrm{M}}^{-} \mathrm{m}_{\mathrm{M}}^{-}$

Characteristics

$\mathrm{Km}^{\mathrm{r}} \mathrm{Tc}^{\mathrm{r}}$

$\mathrm{Km}^{\mathrm{r}}$

$\mathrm{Tc}^{\mathrm{r}}$

$\mathrm{Km}^{\mathrm{r}} \mathrm{Tc} \mathrm{c}^{\mathrm{r}}$

$\mathrm{Km}^{\mathrm{r}} \mathrm{Tc}^{\mathrm{r}}$

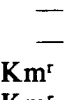

Reference

Imanaka et al. (1982)

Imanaka et al. (1981a)

Reference

Imanaka et al. (1981a)

Imanaka et al. $(1981 a)$

Imanaka et al. (1981a)

Imanaka et al. $(1981 a)$

Imanaka et al. (1982)

Imanaka et al. (1982)

This work

Imanaka et al. $(1981 b)$

This work

* Str ${ }^{r}$, streptomycin resistant.
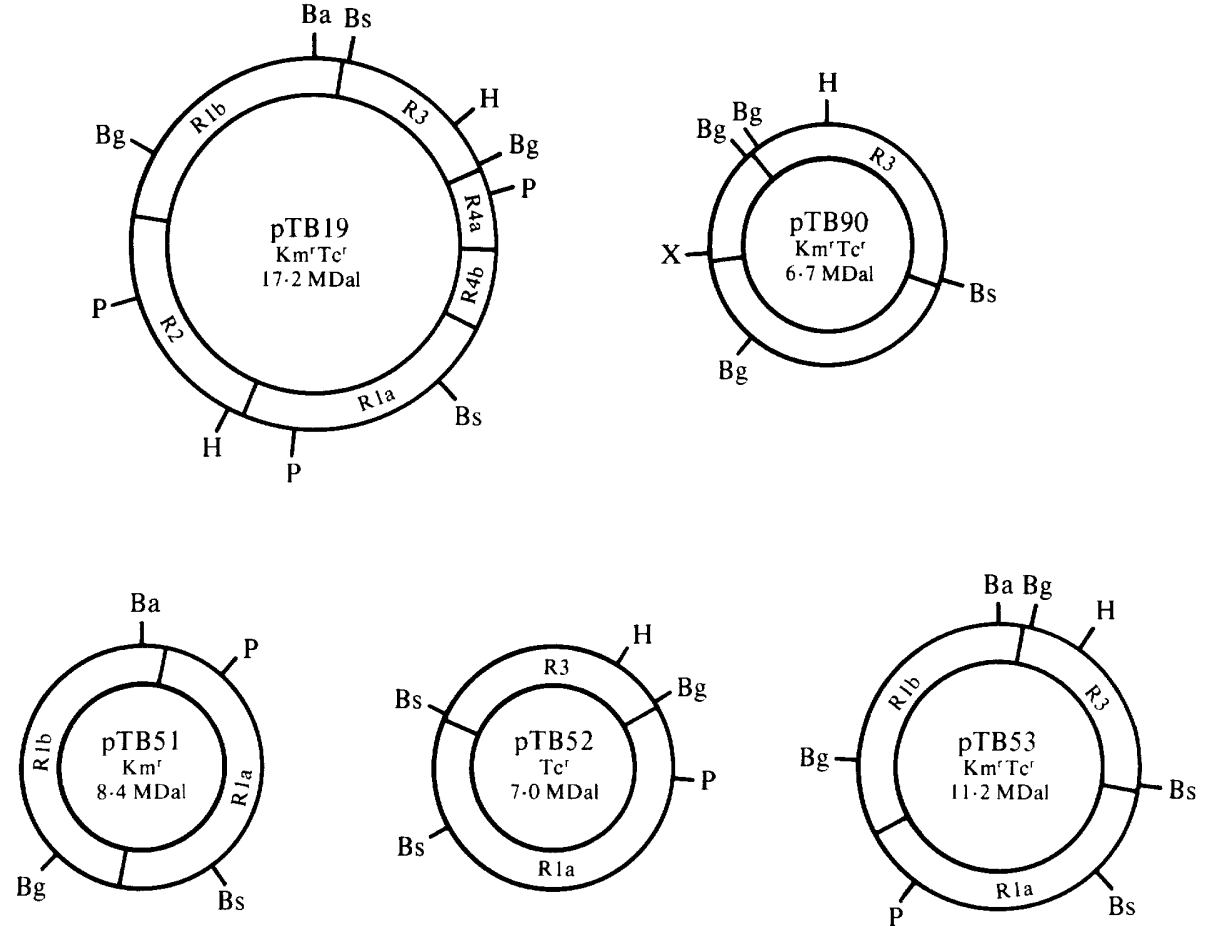

Fig. 1. Restriction endonuclease cleavage maps of plasmids. Cleavage sites of BamHI, BglII, Bst EII,

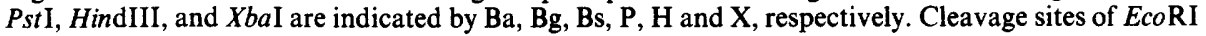
are indicated by the bars inside the circles.

Transformation. Transformation of $B$. stearothermophilus protoplasts with plasmid DNA was done as described by Imanaka et al. (1982). Transformants were selected on regeneration agar containing either kanamycin ( $\mathrm{Km}$; $25 \mu \mathrm{g} \mathrm{ml}^{-1}$ ) or tetracycline ( $\left.\mathrm{Tc} ; 5 \mu \mathrm{g} \mathrm{ml}^{-1}\right)$ and stored on L agar containing $\mathrm{Km}\left(5 \mu \mathrm{g} \mathrm{ml}^{-1}\right)$ or Tc $\left(5 \mu \mathrm{g} \mathrm{ml}{ }^{-1}\right)$ at $4^{\circ} \mathrm{C}$.

Transformation of competent cells of B. subtilis MI113 with plasmid DNA was carried out as described by Imanaka et al. (1981 a). Transformants were selected on L agar containing Km $\left(5 \mu \mathrm{g} \mathrm{ml}^{-1}\right)$ or Tc $\left(25 \mu \mathrm{g} \mathrm{ml}^{-1}\right)$ and stored on the same plates at room temperature.

Assessment of the plasmid copy number. The plasmid copy number was assessed by the procedure of Kieser $e$ t al. (1982) with some modifications. Cells grown in $\mathrm{L}$ broth were harvested by centrifugation $(12000 \mathrm{~g}, 5 \mathrm{~min})$, and washed with TE buffer consisting of $50 \mathrm{mM}-\mathrm{Tris} / \mathrm{HCl}(\mathrm{pH} 8.5)$ and $1 \mathrm{mM}-\mathrm{Na}{ }_{2}$ EDTA. Cells were resuspended in a 
solution of $15 \%$ (w/v) sucrose, $50 \mathrm{mM}$-Tris ( $\mathrm{pH} 8.5$ ), $50 \mathrm{~mm}-\mathrm{Na}_{2}$ EDTA, and $1 \mathrm{mg}$ lysozyme $\mathrm{ml}^{-1}$ for $B$. stearothermophilus ( $5 \mathrm{mg}$ lysozyme $\mathrm{ml}^{-1}$ for $B$. subtilis). The mixture was incubated for $30 \mathrm{~min}$ at $0^{\circ} \mathrm{C}$ in the case of B. stearothermophilus $\left(37^{\circ} \mathrm{C}\right.$ for $\boldsymbol{B}$. subtilis). Lysis was brought about at room temperature by the addition of one volume of a solution containing $1 \%(\mathrm{w} / \mathrm{v})$ Sarkosyl, $50 \mathrm{mM}$-Tris (pH 8.5), and $50 \mathrm{mM}-\mathrm{Na}_{2}$ EDTA, and the mixture was heated at $70^{\circ} \mathrm{C}$ for $5 \mathrm{~min}$ and, after cooling, treated once with phenol, followed by treatment with chloroform. DNA in the aqueous supernatant was concentrated by precipitation with ethanol and then serially diluted in a solution that contained $14 \%(\mathrm{w} / \mathrm{v})$ sucrose, $10 \mathrm{mM}-\mathrm{Na}_{2}$ EDTA, $100 \mu \mathrm{g}$ RNAase $\mathrm{ml}^{-1}$ and $0 \cdot 1 \%$ (w/v) bromophenol blue.

After incubation at $37^{\circ} \mathrm{C}$ for $1 \mathrm{~h}$, samples for each dilution were loaded onto gels for electrophoresis. The gels were stained for $1 \mathrm{~h}$ in ethidium bromide solution $\left(1.0 \mu \mathrm{g} \mathrm{ml}^{-1}\right)$, irradiated with short wavelength $\mathrm{UV}$ to nick closed-circular DNA, and stained for another $1 \mathrm{~h}$ in the ethidium bromide solution. The gels were destained by rinsing with water and photographed with Polaroid type 665 film. The negatives were scanned with a densitometer (PC-910, Shimazu Co., Kyoto, Japan) to measure the peak areas of chromosome and plasmid. The ratio of plasmid to chromosomal DNA was assessed from that of peak areas at a definite dilution, having confirmed that intensities of both peaks on densitometer were proportional to the dilution ratio of the samples. The molecular weights of the chromosomes of $B$. subtilis and B. stearothermophilus were taken as $2 \times 10^{9}$ (Imanaka et al., 1981a).

Nick translation and Southern hybridization. Nick-translated DNA was prepared by using nick translation kit PB 5025 (Amersham). The labelled DNA was freed from low molecular weight materials by passing through a Sephadex G50 column (Pharmacia). Blotting hybridization experiments were carried out by the method of Maniatis et al. (1982).

Other procedures. Other procedures for digestion of plasmid DNA with restriction endonucleases, ligation of DNA and agarose gel electrophoresis are all described elsewhere (Imanaka et al., 1981 a, 1982).

\section{RESULTS}

\section{Description of the host bacterium}

A streptomycin-resistant mutant strain, $\mathrm{S} 1$, which was spontaneously obtained from $B$. stearothermophilus IFO 12550 (ATCC 12980) carried the plasmid pBSO1 (18.3 MDal), which could not be detected as a plasmid in the cured strain CU21 (Imanaka et al., 1982). However, some of the single colonies of CU21 were found during successive transfers on agar plates to have carried another plasmid pBSO2 (19.5 MDal). Plasmid pBSO2 was compared with pBSO1 for restriction endonuclease cleavage sites. Both pBSO1 and pBSO2 prepared by CsCl-ethidium bromide equilibrium density-gradient centrifugation were cleaved with Eco RI, HindIII, BamHI and SalI at 8, 7, 4 and 2 sites, respectively. The digestion patterns of $\mathrm{pBSO} 2$, one of which is shown in Figs 2 and 3 (lane C), were very similar to those of pBSO1. It was most likely that the plasmid pBSO2 might have been integrated into the chromosome of $B$. stearothermophilus CU21. This possibility was examined by Southern transfer, using $\mathrm{pBSO} 2$ as a probe. The chromosomal DNA prepared by $\mathrm{CsCl}$-ethidium bromide equilibrium density-gradient centrifugation from $B$. stearothermophilus CU21, in which the plasmid was not detected, was digested with $E c o$ RI and was subjected to agarose gel electrophoresis. The DNA bands were transferred to a nitrocellulose filter, heated and hybridized with ${ }^{32} \mathrm{P}$-labelled pBSO2. It was shown that pBSO2 hybridized to the chromosomal DNA of $B$. stearothermophilus CU21 (Fig. 3, lanes $\mathrm{D}, \mathrm{d}$ and $\mathrm{d}^{\prime}$ ). It was concluded that the plasmid $\mathrm{pBSO} 2$ was integrated into the chromosomal DNA of $B$. stearothermophilus CU21. This kind of integration of a plasmid into the host chromosome has already been reported for $B$. subtilis (pE194) (Hofemeister et al., 1983). Needless to say, $B$. stearothermophilus CU21, in which no plasmid was detected, was used as the recipient in the transformation experiments.

\section{Comparison of pTB90 with $p T B 19$}

Plasmid pTB19 (17.2 MDal), encoding resistance to both kanamycin and tetracycline, which was originally isolated from a thermophilic bacillus, could transform both $B$. subtilis and $B$. stearothermophilus (Imanaka et al., 1981 a, 1982). Digestion of pTB19 with EcoRI, followed by ligation, yielded deletion plasmids pTB51 $\left(\mathrm{Km}^{\mathrm{r}}\right)$, pTB52 $\left(\mathrm{Tc}^{\mathrm{r}}\right)$, and pTB53 $\left(\mathrm{Km}^{\mathrm{r}} \mathrm{Tc}^{\mathrm{r}}\right)$ in $B$. subtilis (Fig. 1). By restriction enzyme analyses, determinants of $\mathrm{Km}^{\mathrm{r}}, \mathrm{Tc}^{\mathrm{r}}$ and DNA replication were known to be associated with EcoRI fragments R1b, R3, and Rla, respectively 


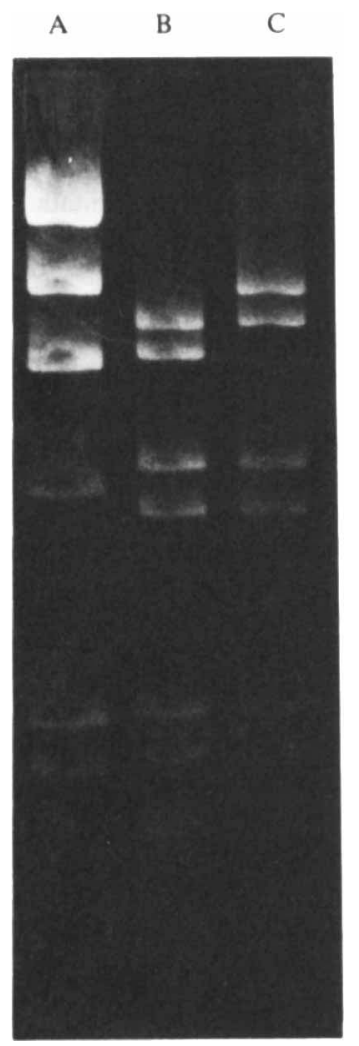

Fig. 2. Restriction endonuclease analyses of plasmids. A, $\lambda$ cI857S7 digested with HindIII (as control); B, pBSO1 digested with EcoRI; C, pBSO2 digested with EcoRI.

(Imanaka et al., 1981a). However, none of the deletion plasmids could transform $B$. stearothermophilus (Imanaka et al., 1982). On the other hand, another deletion plasmid, pTB90, which was constructed from an Eco RI digest of pTB19, could transform both $B$. subtilis and $B$. stearothermophilus. pTB90 was composed of three EcoRI fragments (2.9, 2.8 and 1.0 MDal) and only the $\mathrm{Tc}^{\mathrm{r}}$ determinant clearly corresponded to the $2.8 \mathrm{MDal} E c o$ RI fragment (i.e. the R3 fragment of pTB19) but the other EcoRI fragments (2.9 and 1.0 MDal) were not detected in the original plasmid pTB19 (Imanaka et al., 1982). In order to examine further the correspondence between pTB19 and pTB90, Southern hybridization was done using pTB90 as a probe.

An EcoRI digest of pTB19 was subjected to agarose gel electrophoresis and was transferred to a nitrocellulose filter, followed by hybridization with ${ }^{32}$ P-labelled pTB90. pTB90 hybridized to the EcoRI fragments R1a and/or R1b, R2, and R3 of pTB19, respectively (Fig. 4, lanes A and a). On the other hand, pTB90 only hybridized to the EcoRI fragment R3 of pTB52, which was composed of R1a and R3 (Fig. 4, lanes B and b). Thus, pTB90 hybridized to the EcoRI fragments R1b, R2, and R3 of pTB19.

Restriction endonuclease $X b a I$ could not cleave the DNA of pTB19 (Imanaka et al., 1981 a), whereas the 1.0 MDal EcoRI fragment of pTB90 was cleaved with XbaI at a single site (Fig. 1). This indicates that the 1.0 MDal fragment of pTB90 is not from pTB19. To search for the origin of the 1.0 MDal fragment, pTB19 and pTB90 were subjected to hybridization with the ${ }^{32} \mathrm{P}$ labelled pBSO2. pBSO2 only hybridized to the 1.0 MDal fragment of pTB90 and did not hybridize to pTB19 at all (Fig. 3, lanes A, a, B, b, and ' b'). This was confirmed by the hybridization of ${ }^{32}$ P-labelled pTB90 with the $1.0 \mathrm{MDal}$ EcoRI fragment of pBSO2 (Fig. 4, lanes $\mathrm{C}$ and c). Accordingly, the 2.8 and $1.0 \mathrm{MDal}$ EcoRI fragments of pTB90 were from R3 of pTB19 and the 1.0 MDal Eco RI fragment of pBSO2, respectively. In consequence, it is inferred that the 2.9 MDal EcoRI fragment of pTB90 was from parts of the R1b and R2 fragments of pTB19. 


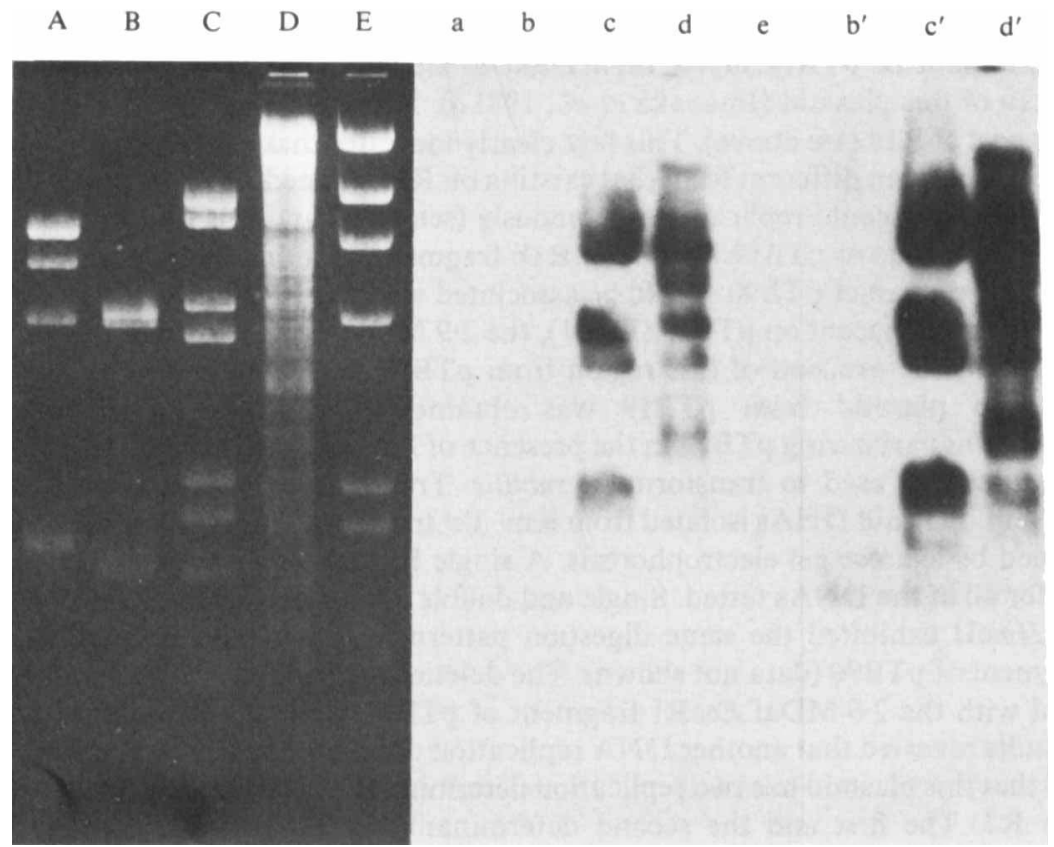

Fig. 3. Hybridization and blotting experiments. Eco RI digests of plasmids were electrophoresed on agarose gel ( $A$ to $E$ ), transferred to a nitrocellulose membrane by blotting, and hybridized to ${ }^{32} \mathrm{P}$ labelled pBSO2 DNA (a to e; b' to d' for a longer exposure). A, a, pTB19; B, b, b', pTB90; C, c, c', pBSO2; D, d, d', chromosomal DNA of the strain CU21; E, e, $\lambda$ cI857S7 digested with HindIII.

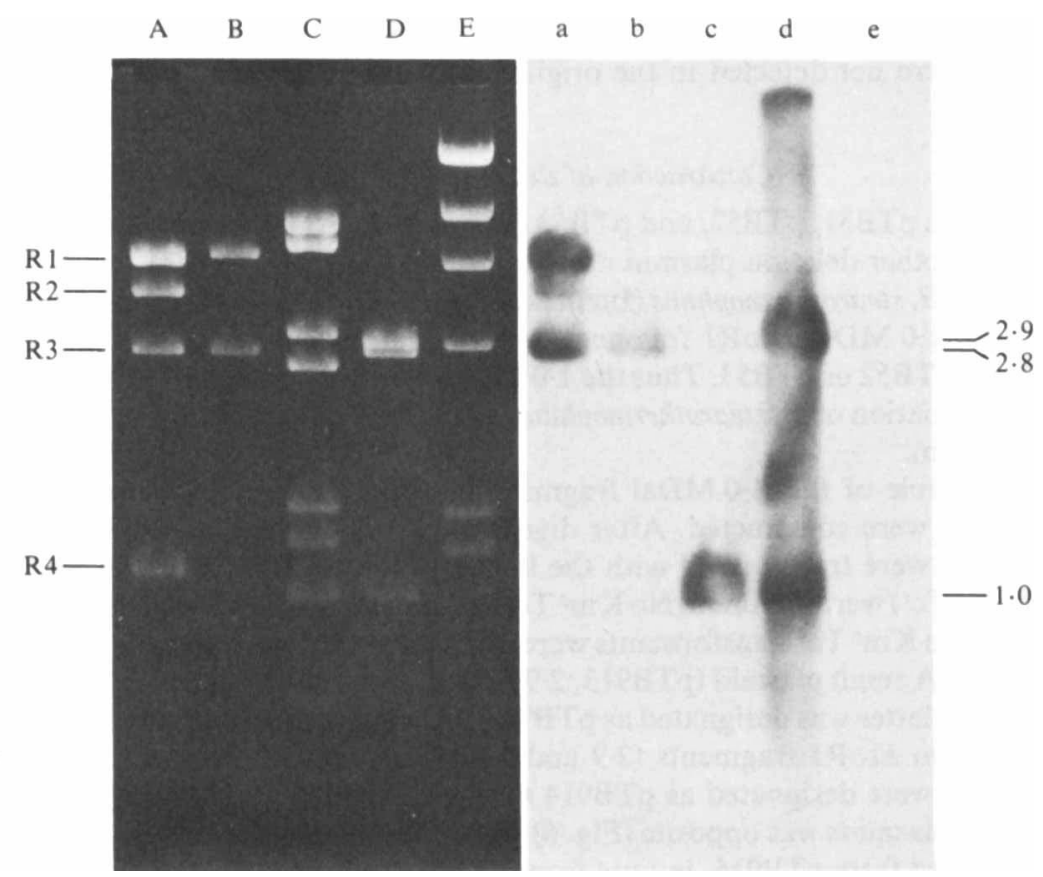

Fig. 4. Hybridization and blotting experiments (continued). EcoRI digests of plasmids were electrophoresed on agarose gel (A to E), transferred to a nitrocellulose membrane by blotting, and hybridized to ${ }^{32}$ P-labelled pTB90 DNA (a to e). A, a, pTB19; B, b, pTB52; C, c, pBSO2; D, d, pTB90; E, e, $\lambda c I 857 S 7$ digested with HindIII. R1 to R4 on the left-hand side are EcoRI fragments of pTB19 (Imanaka et al., 1982); the numbers on the right-hand side are molecular sizes (MDal) of relevant DNA fragments. 


\section{Replication determinant of pTB90}

The determinant of pTB19 DNA replication is known to be associated with the Eco RI fragment R1a of this plasmid (Imanaka et al., 1981 a). However, its derivative pTB90 did not contain any part of R1a (see above). This fact clearly indicates that pTB90 should have another replication determinant different from that existing on R1a. Indeed, the largest Eco RI fragment (2.9 MDal) of pTB90 could replicate autonomously (see later) and this fragment was from the $R 1 b$ and $R 2$ fragments of $p T B 19$. Since the $R 1 b$ fragment contains the $\mathrm{Km}^{\mathrm{r}}$ determinant, the replication determinant of pTB90 should be associated with the R2 fragment. Since the R2 and R1b fragments are adjacent on pTB19 (Fig. 1), the 2.9 MDal EcoRI fragment of pTB90 might have emerged by the excision of this region from pTB19.

The deletion plasmid from pTB19 was obtained as follows. After cultivating $B$. stearothermophilus harbouring pTB19 in the presence of $\mathrm{Km}$, plasmid DNA was extracted from this culture and was used to transform $B$. subtilis. Transformants were selected on L agar containing $\mathrm{Km}$. Plasmid DNAs isolated from $\mathrm{Km}^{\mathrm{r}} \mathrm{Tc}^{\mathrm{s}}$ transformants were digested with Eco RI and examined by agarose gel electrophoresis. A single band which corresponded to $2.9 \mathrm{MDal}$ was found for all of the DNAs tested. Single and double digestions of this plasmid with $E c o$ RI, $B g l \mathrm{II}$ and HincII exhibited the same digestion pattern to that obtained from the $2.9 \mathrm{MDal}$ $E c o$ RI fragment of pTB90 (data not shown). The deletion plasmid was therefore considered to be identical with the $2.9 \mathrm{MDal}$ Eco RI fragment of pTB90, and was designated as pTB913.

These results revealed that another DNA replication determinant was on the $R 2$ fragment of pTB19 and that this plasmid has two replication determinants, i.e. the one on fragment Rla and another on R2. The first and the second determinants for the replication of pTB19 were designated RepA and RepB, respectively. It was shown that pTB90 contained RepB of pTB19 but not RepA. It is inferred that pTB90 was constructed according to the scheme shown in Fig. 5. The DNA sample of pTB19 when prepared from B. stearothermophilus CU21 may have contained a small amount of both pTB913 and pBSO2. pTB90 was obtained at relatively low efficiency from the ligation mixture of the EcoRI digest of the DNA sample. The scheme of Fig. 5 would account for the observation that pTB90 contained 2.9 MDal and 1.0 MDal Eco RI fragments which were not detected in the original plasmid pTB19.

\section{Construction of deletion plasmids}

Deletion plasmids pTB51, pTB52, and pTB53 derived from pTB19 could replicate only in $B$. subtilis, whereas another deletion plasmid derived from pTB19, viz. pTB90, could replicate in both $B$. subtilis and $B$. stearothermophilus (Imanaka et al., 1982). However, pTB90 contained the specific fragment (1.0 MDal EcoRI fragment) which came from $\mathrm{pBSO} 2$ but which was not present in pTB51, pTB52 or pTB53. Thus the $1.0 \mathrm{MDal}$ fragment of pTB90 played a significant role in the transformation of $B$. stearothermophilus, i.e. in the replication or maintenance of the plasmid in the strain.

To examine the role of this $1.0 \mathrm{MDal}$ fragment in $B$. stearothermophilus, various deletion plasmids of pTB90 were constructed. After digestion of pTB90 with EcoRI and ligation, $B$. subtilis MI113 cells were transformed with the ligation mixture. Two kinds of transformants $\left(\mathrm{Km}^{\mathrm{r}} \mathrm{Tc}^{\mathrm{s}}\right.$ and $\left.\mathrm{Km}^{\mathrm{r}} \mathrm{Tc}^{\mathrm{r}}\right)$ were obtained. No $\mathrm{Km}^{\mathrm{s}} \mathrm{Tc}^{\mathrm{r}}$ transformants were obtained. Plasmid DNA species isolated from $\mathrm{Km}^{\mathrm{r}} \mathrm{Tc}^{\mathrm{s}}$ transformants were digested with $E c o \mathrm{RI}$ and analysed by agarose gel electrophoresis. A small plasmid (pTB913, 2.9 MDal) and a large plasmid (2.9 + 1.0 MDal) were found, and the latter was designated as pTB919. Two different deletion plasmids that were composed of the two EcoRI fragments $(2.9$ and $2.8 \mathrm{MDal})$ could be obtained from $\mathrm{Km}^{\mathrm{r}} \mathrm{Tc}^{\mathrm{r}}$ transformants, and were designated as pTB914 and pTB916. The direction of the two Eco RI fragments of these plasmids was opposite (Fig. 6). Another deletion plasmid ( $\mathrm{Tc}^{\mathrm{r}}$ ) designated as pTB902 was obtained from pTB916, but not from pTB914. Furthermore, pTB913 and pTB902 were digested with $E c o$ RI and ligated, respectively, with the $1.0 \mathrm{MDal} E c o$ RI fragment. These ligation mixtures were used to transform $B$. subtilis. The recombinant plasmids (pTB913 + 1.0 MDal, pTB902 + 1.0 MDal) were designated as pTB931 and pTB921, respectively. Two EcoRI fragments (2.9 and 1.0 MDal) of pTB931 and pTB919 were connected in the opposite 


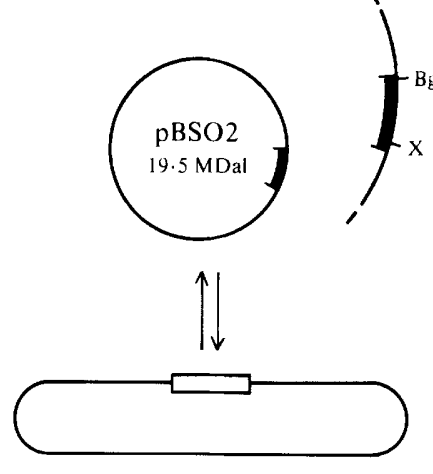

B. stearothermophilus

CU21 chromosome

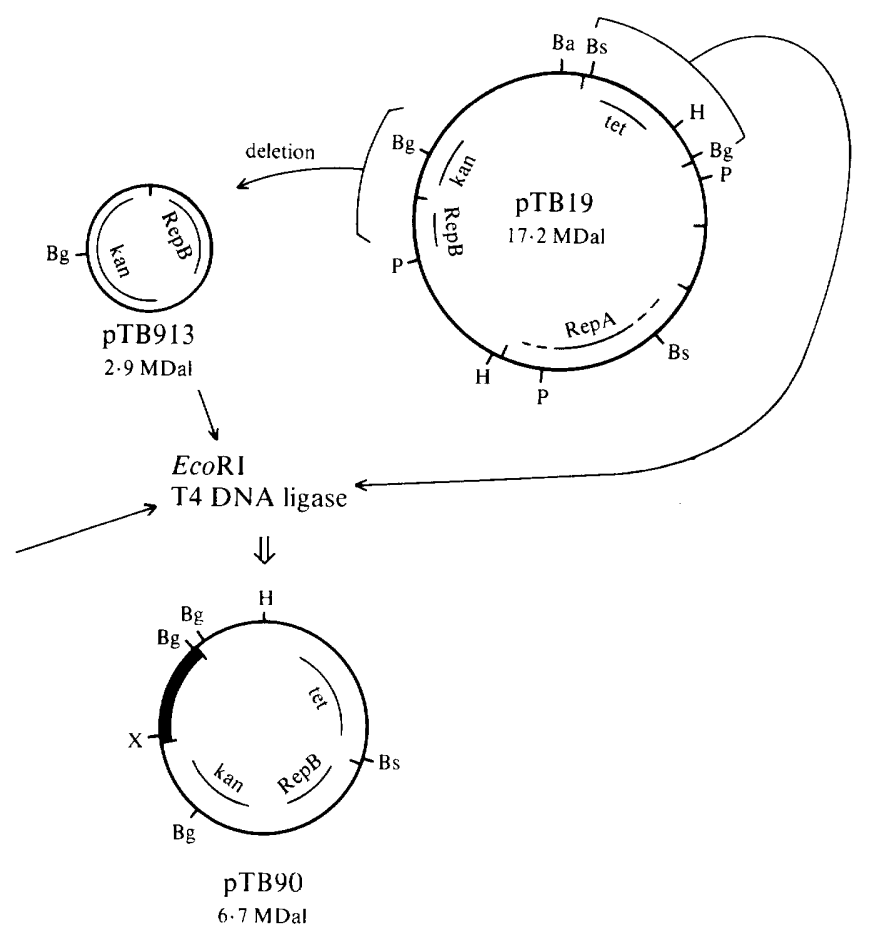

Fig. 5. A schematic diagram of the construction of pTB90 in vitro. This would indicate that the three EcoRI fragments (2.9, 2.8 and 1.0 MDal) composing pTB90 were from pTB913, pTB19, and pBSO2, respectively. Cleavage sites of $B a m \mathrm{HI}, B g l \mathrm{II}, B s t \mathrm{EII}$, Pst I, HindIII, and $X b a \mathrm{I}$ are indicated by Ba, Bg, $\mathrm{Bs}, \mathrm{P}, \mathrm{H}$, and $\mathrm{X}$, respectively. The bars inside the circles indicate the cleavage sites of EcoRI. The heavy line corresponds to the 1.0 MDal EcoRI fragment.

direction to each other. Restriction endonuclease cleavage maps of these plasmids are summarized in Fig. 6.

Transformation of $B$. stearothermophilus with various deletion plasmids from pTB90

Bacillus stearothermophilus CU21 was transformed with pTB90 and its derivatives (Table 2). The plasmids in this series of tests were all prepared from $B$. subtilis, but pTB90 used in experiment 2 was prepared from $B$. stearothermophilus to modify the BstEII site.

In transformation experiment 1 , about $1 \times 10^{3}$ transformants were obtained with $1 \mu \mathrm{g}$ pTB90, but no antibiotic-resistant transformants were obtained with $1 \mu \mathrm{g}$ pTB914 or pTB916. In experiment 2 , the transformation frequency with pTB913 lacking 1.0 MDal Eco RI fragment was about $10^{-4}$ times those with pTB919 and pTB931, both of which carried 1.0 MDal Eco RI fragment. Of the plasmids not carrying the 1.0 MDal EcoRI fragment (pTB914, pTB916 and pTB913), only pTB913 gave some transformants. The difference between pTB913 and the other two plasmids (pTB914 and pTB916) might be accounted for as follows: pTB914 and pTB916 contain the restriction endonuclease cleavage site for $B s t$ EII, the isoschizomer of $B s t$ PI from $B$. stearothermophilus ATCC 12980, while pTB913 had no site for BstEII (Fig. 6). Indeed, a few transformants were obtained when $10 \mu \mathrm{g}$ rather than $1 \mu \mathrm{g}$ DNA of pTB914 or pTB916 was used.

The results of experiments 1 and 2 suggested that the transformation frequency of $B$. stearothermophilus was significantly enhanced by the $1.0 \mathrm{MDal} E c o$ RI fragment. To confirm this point, transformation frequencies for pTB902 and pTB921 were determined in experiment 3 . No transformants were obtained from pTB902 (lacking the $1.0 \mathrm{MDal}$ fragment), but $1.8 \times 10^{4}$ transformants were obtained with $1 \mu$ g DNA of pTB921 carrying the $1.0 \mathrm{MDal}$ fragment. 


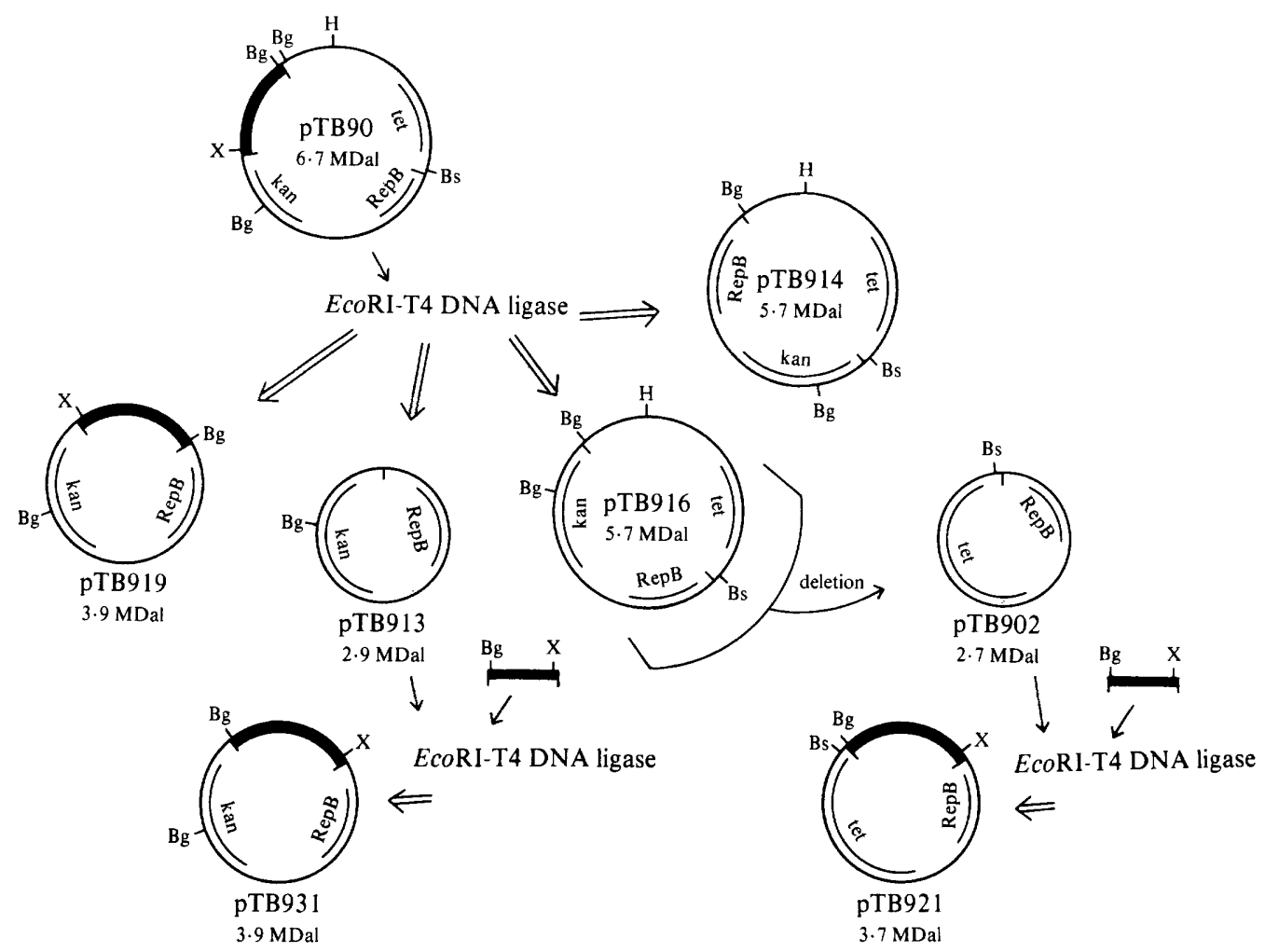

Fig. 6. Restriction endonuclease cleavage maps of plasmids. Cleavage sites of BglII, BstEII, HindIII, and $\mathrm{Xba \textrm {I }}$ are indicated by $\mathrm{Bg}, \mathrm{Bs}, \mathrm{H}$, and $\mathrm{X}$, respectively. The bars inside the circles indicate the cleavage sites of EcoRI. The heavy line corresponds to the 1.0 MDal EcoRI fragment.

Table 2. Transformation of B. stearothermophilus CU21 with plasmid DNA

\begin{tabular}{|c|c|c|c|c|c|c|}
\hline $\begin{array}{c}\text { Expt } \\
\text { no. }\end{array}$ & Plasmid & BstEII & $\begin{array}{c}\text { 1.0 MDal } \\
\text { EcoRI } \\
\text { fragment }\end{array}$ & $\begin{array}{l}\text { Antibiotic } \\
\text { selection* }\end{array}$ & $\begin{array}{l}\text { Transformants } \\
\text { per } \mu \mathrm{g} \text { of DNA }\end{array}$ & $\begin{array}{c}\text { Transformation } \\
\text { frequency per } \\
\text { regenerant } \dagger\end{array}$ \\
\hline 1 & $\begin{array}{l}\text { pTB90 } \\
\text { pTB90 } \\
\text { pTB914 } \\
\text { pTB914 } \\
\text { pTB916 } \\
\text { pTB916 }\end{array}$ & $\begin{array}{l}+ \\
+ \\
+ \\
+ \\
+ \\
+\end{array}$ & $\begin{array}{l}+ \\
+ \\
- \\
- \\
-\end{array}$ & $\begin{array}{l}\mathrm{Km} \\
\mathrm{Tc} \\
\mathrm{Km} \\
\mathrm{Tc} \\
\mathrm{Km} \\
\mathrm{Tc}\end{array}$ & $\begin{aligned} 1.9 & \times 10^{3} \\
7.7 & \times 10^{2} \\
& <1 \\
& <1 \\
& <1 \\
& <1\end{aligned}$ & $\begin{array}{l}1.6 \times 10^{-4} \\
6.4 \times 10^{-5} \\
<8 \times 10^{-8} \\
<8 \times 10^{-8} \\
<8 \times 10^{-8} \\
<8 \times 10^{-8}\end{array}$ \\
\hline 2 & $\begin{array}{l}\text { pTB90 } \\
\text { pTB913 } \\
\text { pTB919 } \\
\text { pTB931 }\end{array}$ & $\begin{array}{l}+\ddagger \\
- \\
- \\
-\end{array}$ & $\begin{array}{l}+ \\
- \\
+ \\
+\end{array}$ & $\begin{array}{l}\mathrm{Km} \\
\mathrm{Km} \\
\mathrm{Km} \\
\mathrm{Km}\end{array}$ & $\begin{array}{l}1.0 \times 10^{7} \\
4.6 \times 10^{1} \\
2.2 \times 10^{5} \\
5.2 \times 10^{5}\end{array}$ & $\begin{array}{l}1.9 \times 10^{-1} \\
8.8 \times 10^{-7} \\
4.2 \times 10^{-3} \\
1.0 \times 10^{-2}\end{array}$ \\
\hline 3 & $\begin{array}{l}\text { pTB90 } \\
\text { pTB902 } \\
\text { pTB921 }\end{array}$ & $\begin{array}{l}+ \\
+ \\
+\end{array}$ & $\begin{array}{l}+ \\
- \\
+\end{array}$ & $\begin{array}{l}\text { Tc } \\
\text { Tc } \\
\text { Tc }\end{array}$ & $\begin{array}{c}8.6 \times 10^{3} \\
<1 \\
1.8 \times 10^{4}\end{array}$ & $\begin{array}{l}6.1 \times 10^{-5} \\
<7 \times 10^{-9} \\
1.3 \times 10^{-4}\end{array}$ \\
\hline
\end{tabular}

* Selection was on kanamycin, $25 \mu \mathrm{g} \mathrm{ml}^{-1}(\mathrm{Km})$ or tetracycline, $5 \mu \mathrm{g} \mathrm{ml}^{-1}(\mathrm{Tc})$.

$\dagger$ Regenerated protoplasts for experiments 1,2 and 3 were $1.2 \times 10^{7}, 5.2 \times 10^{7}$, and $1.4 \times 10^{8} \mathrm{ml}^{-1}$, respectively. $\ddagger$ Since the plasmid was prepared from $B$. stearothermophilus, the BstEII site was modified.

Therefore the 1.0 MDal EcoRI fragment could enhance the transformation frequency for $B$. stearothermophilus. A few transformants were also obtained when $10 \mu \mathrm{g}$ DNA of pTB902 having the site for BstEII was used. The difference in transformation frequencies for pTB90 in each experiment might be due to differences in the modification of the BstEII site. 
Table 3. Properties of plasmids

\begin{tabular}{|c|c|c|c|c|c|c|}
\hline Plasmid & Characteristics & Rep & $\begin{array}{c}1.0 \mathrm{MDal} \\
E c o \mathrm{RI} \\
\text { fragment }\end{array}$ & $\begin{array}{l}\text { Copy no. in } \\
\text { B. subtilis }\end{array}$ & $\begin{array}{l}\text { Transformation of } \\
\text { B. stearothermophilus }\end{array}$ & $\begin{array}{l}\text { Copy no. in } \\
\text { B. stearothermophilus }\end{array}$ \\
\hline pTB19 & $\mathbf{K m}^{\mathrm{r}} \mathrm{Tc}^{\mathrm{r}}$ & A, B & - & $1^{*}$ & + & $1^{*}$ \\
\hline pTB51 & $\mathrm{Km}^{\mathrm{r}}$ & A & - & 8 & - & - \\
\hline pTB52 & $T c^{r}$ & A & - & 9 & - & - \\
\hline pTB53 & $\mathrm{Km}^{\mathrm{r}} \mathrm{Tc}^{\mathrm{r}}$ & A & - & 8 & - & - \\
\hline pTB90 & $\mathbf{K m}^{\mathrm{r}} \mathbf{T c}^{\mathrm{r}}$ & B & + & 11 & + & 5 \\
\hline pTB914 & $\mathrm{Km}^{\mathrm{r}} \mathrm{Tc}^{r}$ & B & - & 13 & $+\dagger$ & 43 \\
\hline pTB916 & $\mathrm{Km}^{\mathrm{r}} \mathrm{Tc}^{\mathrm{r}}$ & B & - & 15 & $+\dagger$ & $-\ddagger$ \\
\hline рТВ913 & $\mathrm{Km}^{\mathrm{r}}$ & B & - & 25 & $+\dagger$ & $39^{\circ}$ \\
\hline рТВ919 & $\mathrm{Km}^{r}$ & B & + & 13 & + & 5 \\
\hline pTB931 & $\mathbf{K m}^{\mathrm{r}}$ & B & + & 14 & + & 4 \\
\hline pTB902 & $\mathrm{Tc}^{\mathrm{r}}$ & B & - & 24 & $+\dagger$ & 60 \\
\hline \multirow[t]{2}{*}{ pTB921 } & $\mathrm{Tc}^{\mathrm{r}}$ & B & + & 13 & + & 7 \\
\hline & & & eti & appea & $\begin{array}{l}\text { 32). } \\
\text { uently. }\end{array}$ & \\
\hline
\end{tabular}

Copy number of plasmids

The copy numbers of plasmids carrying the 1.0 MDal EcoRI fragment were about one-tenth of those of plasmids lacking this fragment in $B$. stearothermophilus. However, copy numbers of plasmids with and without the 1.0 MDal Eco RI fragment did not differ appreciably in $B$. subtilis (Table 3).

\section{DISCUSSION}

It is shown in this paper that pTB19 isolated from a thermophilic bacillus had two distinct DNA segments capable of autonomous replication. This finding is the first report of a specific plasmid from the genus Bacillus, having two replication determinants on the same replicon. A deletion plasmid pTB913 $\left(\mathrm{Km}^{\mathrm{r}}\right)$ was isolated from pTB19 $\left(\mathrm{Km}^{\mathrm{r}} \mathrm{Tc} \mathrm{c}^{\mathrm{r}}\right)$ in $B$. stearothermophilus (Fig. 5). The same deletion plasmid $\left(\mathrm{Km}^{\mathrm{r}}, 2.9 \mathrm{MDal}\right)$ was also obtained from pTB19 in $B$. subtilis. In addition, another deletion plasmid $\left(\mathrm{Tc}^{\mathrm{r}}\right.$, about $\left.14 \mathrm{MDal}\right)$ was observed in $B$. subtilis (data not shown). These results suggest that the two deletion plasmids emerged from pTB19 $\left(\mathrm{Km}^{\mathrm{r}} \mathrm{Tc}, 17.2 \mathrm{MDal}\right)$ by in vivo recombination and, conversely, pTB19 might have been constructed by in vivo fusion of two distinct plasmids specifying resistance to $\mathrm{Km}$ and $\mathrm{Tc}$, respectively, in a host bacterium. It has been reported that many drug-resistance plasmids ( $R$ plasmids) of Enterobacteriaceae are composite replicons (Danbara et al., 1980; Perlman \& Rownd, 1976; Yoshikawa, 1974).

Deletion plasmids containing RepA (pTB51, pTB52 and pTB53) derived from pTB19 could replicate only in $B$. subtilis, while other plasmids containing RepB (pTB19, pTB90 and its derivatives) could replicate in both $B$. subtilis and $B$. stearothermophilus. Further, copy numbers of $\mathrm{RepA}^{+}$plasmids in $B$. subtilis were somewhat lower than those of RepB ${ }^{+}$plasmids (Table 3 ). These facts would justify that the two determinants, RepA and RepB, responsible for DNA replication, are different. The precise nature of these determinants, such as whether they are replication origins, is now under investigation.

The 1.0 MDal EcoRI fragment which combined RepB from pTB90 significantly enhanced the transformation frequency for $B$. stearothermophilus and reduced copy number (Tables 2 and 3 ). The increase of transformation frequency might be partly explained by the possibility of recombinational rescue during transformation due to homology between the $1.0 \mathrm{MDal} E c o \mathrm{RI}$ fragment of the incoming plasmid and like-sequences on the $B$. stearothermophilus chromosome. To examine this possibility, another recombinant plasmid, pUB111, was constructed by inserting the 1.0 MDal EcoRI fragment into EcoRI cleavage site of pUB110. The transformation frequency of $B$. stearothermophilus with pUB111 was nearly the same as that 
with pUB110 (data not shown). Thus, it seems most unlikely that the 1.0 MDal EcoRI fragment assists transformation by homology of the incoming plasmid with the chromosome. Copy numbers of pUB110 and pUB111 in B. stearothermophilus were nearly the same. Once the plasmids were satisfactorily transferred into the host cells, each plasmid was stably maintained in B. stearothermophilus irrespective of the presence or absence of the 1.0 MDal EcoRI fragment (data not shown). These results suggest that the 1.0 MDal Eco RI fragment of pTB90 could be responsible for the regulation of RepB function, including plasmid DNA replication and copy number control. Possible genetic information encoded in this $1.0 \mathrm{MDal} E c o$ RI fragment might include the following: (i) a protein which acts negatively for the initiation of the plasmid replication (because it reduces the copy number in $B$. stearothermophilus); (ii) a small RNA which inhibits the initiation of plasmid replication as reported for plasmids ColE1 and R1 (Stougaard et al., 1981; Tomizawa \& Itoh, 1981); and (iii) a replication origin available only in $B$. stearothermophilus but not in B. subtilis. The growth rate of $B$. subtilis (pUB111) in L broth was $40 \%$ lower than that of $B$. subtilis (pUB110). The colonies of these two strains on $L$ agar were clearly different in size and appearance, suggesting that the gene product of the 1.0 MDal Eco RI fragment gave rise to a stress to host cells. However, this kind of difference was not observed between $B$. stearothermophilus (pUB111) and B. stearothermophilus (pUB110). These phenomena indicate that the phenotypic expression of this 1.0 MDal EcoRI fragment is considerably influenced by both the vector plasmid and the host bacterium. DNA sequencing and analysis of the gene products are now in progress to provide an insight into the mechanism that controls plasmid DNA replication in these mesophilic and thermophilic bacteria.

We thank M. Mizutani of this department for his technical assistance in this study.

\section{REFERENCES}

Danbara, H., Timmis, J. K., LURz, R. \& Timmis, K. N. (1980). Plasmid replication functions: two distinct segments of plasmid R1, RepA and RepD, express incompatibility and are capable of autonomous replication. Journal of Bacteriology 144, 1126-1138.

Hofemeister, J., ISRAeli-Reches, M. \& DubNaU, D. (1983). Integration of plasmid pE194 at multiple sites on the Bacillus subtilis chromosome. Molecular and General Genetics 189, 58-68.

ImANAKA, T., FUjII, M. \& AIBA, S. (1981a). Isolation and characterization of antibiotic resistance plasmids from thermophilic bacilli and construction of deletion plasmids. Journal of Bacteriology 146, 10911097.

Imanaka, T., Tanaka, T., Tsunekawa, H. \& Aiba, S. $(1981 b)$. Cloning of the genes for penicillinase, penP and penI, of Bacillus licheniformis in some vector plasmids and their expression in Escherichia coli, Bacillus subtilis, and Bacillus licheniformis. Journal of Bacteriology 147, 776-786.

ImANAKa, T., Fujil, M., ARAmori, I. \& Aiba, S. (1982). Transformation of Bacillus stearothermophilus with plasmid DNA and characterization of shuttle vector plasmids between Bacillus stearothermophilus and Bacillus subtilis. Journal of Bacteriology 149, 824-830.

Kieser, T., HopWOOD, D. A., Wright, H. M. \&
ThOMPson, C. J. (1982). pIJ101, a multi-copy broad host-range Streptomyces plasmid: functional analysis and development of DNA cloning vectors. Molecular and General Genetics 185, 223-238.

Maniatis, T., Fritsch, E. F. \& SambrooK, J. (1982). Southern transfer. In Molecular Cloning, a Laboratory Manual, pp. 382-389. New York: Cold Spring Harbor Laboratory.

Perlman, D. \& Rownd, R. H. (1976). Two origins of replication in composite $\mathrm{R}$ plasmid DNA. Nature, London 259, 281-284.

StougaArd, P., Molin, S. \& Nordström, K. (1981). RNAs involved in copy-number control and incompatibility of plasmid R1. Proceedings of the National Academy of Sciences of the United States of America 78, 6008-6012.

Tomizawa, J. \& IтoH, T. (1981). Plasmid ColEl incompatibility determined by interaction of RNAI with primer transcript. Proceedings of the National Academy of Sciences of the United States of America 78, 6096-6100.

YoshIKAWA, M. (1974). Identification and mapping of the replication genes of an $\mathrm{R}$ factor, $\mathrm{R} 100-1$, integrated into the chromosome of Escherichia coli K-12. Journal of Bacteriology 118, 1123-1131. 